\title{
Benzamide riboside induces apoptosis independent of Cdc25A expression in human ovarian carcinoma N.1 cells
}

\author{
Michael Grusch ${ }^{1}$, Georg Rosenberger ${ }^{1}$, Gerhard Fuhrmann ${ }^{1}$, \\ Katja Braun ${ }^{2}$, Birgit Titscher ${ }^{1}$, Thomas Szekeres ${ }^{3}$, \\ Monika Fritzer-Skekeres ${ }^{3}$, Georg Oberhuber ${ }^{1}$, \\ Karsten $\mathrm{Krohn}^{4}$, Markus Hengstschlaeger ${ }^{2}$, \\ Georg Krupitza ${ }^{1}$ and Hiremagalur N. Jayaram ${ }^{\star, 5,6}$ \\ ${ }^{1}$ Institute of Clinical Pathology, University of Vienna, Währinger Gürtel 18-20, \\ A-1090 Vienna, Austria \\ 2 Department of Prenatal Diagnostic, Institute of Gynecology and Obstetrics, \\ University of Vienna, Währinger Gürtel 18-20, A-1090 Vienna, Austria \\ ${ }^{3}$ Clinical Institute of Medical and Chemical Laboratory Diagnostics, University of \\ Vienna, Währinger Gürtel 18-20, A-1090 Vienna, Austria \\ ${ }^{4}$ Division of Organic Chemistry, Universität Gesamthochschule Paderborn, \\ Paderborn, 1621-4790, Germany \\ ${ }^{5}$ Laboratory of Experimental Oncology, Indiana University School of Medicine, \\ Indianapolis, IN 46202-5119, USA \\ ${ }^{6}$ Department of Biochemistry and Molecular Biology, Indiana University School \\ of Medicine, Indianapolis, IN 46202-5119, USA \\ * corresponding author: Hiremagalur N. Jayaram, Ph.D., Department of \\ Biochemistry and Molecular Biology, and Laboratory for Experimental \\ Oncology, Indiana University School of Medicine, 699 West Drive RR 337, \\ Indianapolis, IN 46202-5119, USA. tel: (317) 274-3709; fax: (317) 274-3939; \\ e-mail: hjayaram@iupui.edu
}

Received 28.12.98; revised 22.4.99; accepted 20.5.99

Edited by L. Fesus

\begin{abstract}
One of the mechanisms of action of a new oncolytic agent, benzamide riboside (BR) is by inhibiting inosine $5^{\prime}$-monophosphate dehydrogenase (IMPDH) which catalyzes the formation of xanthine $5^{\prime}$-monophosphate from inosine $5^{\prime}$ monophosphate and nicotinamide adenine dinucleotide, thereby restricting the biosynthesis of guanylates. In the present study BR $(10-20 \mu \mathrm{M})$ induced apoptosis in a human ovarian carcinoma N.1 cell line (a monoclonal derivative of its heterogenous parent line HOC-7). This was ascertained by DNA fragmentation, TUNEL assay, [poly(ADP)ribose polymerase]-cleavage and alteration in cell morphology. Apoptosis was accompanied by sustained c-Myc expression, concurrent down-regulation of cdc25A mRNA and protein, and by inhibition of Cdk2 activity. Both Cdk2 and cdc25A are $G_{1}$ phase specific genes and Cdk2 is the target of Cdc25A. These studies demonstrate that $B R$ exhibits dual mechanisms of action, first by inhibiting IMPDH, and second by inducing apoptosis, which is associated with repression of components of the cell cycle that are downstream of constitutive cMyc expression.
\end{abstract}

Keywords: IMP dehydrogenase inhibitor; benzamide riboside; apoptosis; cdc25A repression; cyclin D1/prad 1 expression; c-myc induction

\begin{abstract}
Abbreviations: ATP, adenosine triphosphate; ATRA, all-trans retinoic acid; $B A D$, benzamide adenine dinucleotide; BR, 3-(1deoxy- $\beta$-D-ribofuranosyl)benzamide or Benzamide riboside; Cdk2, cyclin dependent kinase 2; dGTP, 2'-deoxyguanosine 5'-triphosphate; DTT, DL-dithiothreitol; EDTA, ethylenediaminetetraacetic acid; FCS, fetal calf serum; GAPDH, glyceraldehyde-3-phosphate dehydrogenase; gas6, growth arrest specific 6 gene; GTP, guanosine 5'-triphosphate; HEPES, (N-[2-hydroxyethyl]piperazine- $\mathrm{N}^{\prime}$-[4-butansulfonic acid]); IMP, inosine 5'monophosphate; IMPDH, inosine $5^{\prime}$-monophosphate dehydrogenase; MEM, alpha minimal essential medium; NAD, nicotinamide adenine dinucleotide; NGF, nerve growth factor; PARP, poly(ADPribose)polymerase; PBS, phosphate-buffered saline; PDGF, platelet derived growth factor; PI, propidium iodide, PMSF, phenylmethylsulfonyl fluoride; SDS, sodium dodecyl sulfate; SDSPAGE, SDS-polyacrylamide gel; TAD, thiazole-4-carboxamide adenine dinucleotide; TNFalpha, tumor necrosis factor alpha; TNFbeta, tumor necrosis factor beta; TR, 2- $\beta$-D-ribofuranosylthiazole-4-carboxamide or tiazofurin; TUNEL terminal deoxynucleotidyl transferase (TdT)-mediated dUTP-X nick end labelling; XMP, xanthine 5'-monophosphate; z-VAD-fmk, benzyloxylcarbonyl ValAla-DL-Asp-fluoromethylketone
\end{abstract}

\section{Introduction}

Ovarian carcinoma is one of the most lethal gynecological malignancies. To improve the prognosis, there is a need to develop new therapeutic concepts. Since little is known about the molecular mechanisms by which ovarian carcinomas bypass homeostasis, a knowledge of the expression of genes which function in growth-, survival- and death-control would be beneficial.

IMP dehydrogenase (IMPDH) catalyzes the conversion of IMP to XMP and is the rate limiting enzyme in de novo guanylate biosynthesis. ${ }^{1}$ The activity of this enzyme was shown to be significantly increased in tumor cells and therefore considered to be a potential target for cancer chemotherapy. ${ }^{2}$ Tiazofurin (TR) was found to inhibit the growth of human myelogenous leukemia $\mathrm{K} 62^{3}$ and human promyelocytic leukemia HL-60 cells. ${ }^{4}$ TR was shown to be an inhibitor of $\mathrm{IMPDH}^{5}$ and Phase $\mathrm{I} / \mathrm{II}$ clinical trials conducted with tiazofurin in acute myelogenous leukemia patients, indicated a significant reduction in leukemic cell burden. ${ }^{6-8}$

Benzamide riboside, BR, is a C-nucleoside, ${ }^{9}$ which has recently been characterized as having IMPDH inhibitory properties. ${ }^{10,11} \mathrm{BR}$ exhibited stronger antiproliferative activity in the K562 cells than TR. ${ }^{12}$

The two nucleoside antimetabolites, TR and BR are converted in cancer cells to their active dinucleotide metabolites, TAD (thiazole-4-carboxamide adenine dinucleotide) and BAD (benzamide adenine dinucleotide), which are analogues of $N A D$, wherein the nicotinamide moiety is 
replaced by their respective bases. ${ }^{11,13}$ BAD potently inhibits NAD utilization by IMPDH, resulting in the depletion of intracellular guanylate concentrations including GTP and dGTP.

The human ovarian carcinoma N.1 cell line (a monoclonal derivative of the heterogenous parent $\mathrm{HOC}-7$ line) is useful to study the induction of growth arrest, differentiation and apoptosis. ${ }^{14,15}$ By analyzing cell morphology, DNA integrity and gene expression, the cytotoxic properties of oncolytic agents can be determined in a first screen. ${ }^{16}$

Therefore, in this report, N.1 cells were utilized to examine the influence of BR on $\mathrm{N} .1$ cell proliferation and to get an insight into the physiological and molecular aspects of antiproliferative mechanisms. Induction of apoptosis by BR was ascertained by distinguishing changes in morphology, DNA fragmentation, TUNEL assay, and [poly (ADP) ribose polymerase] cleavage. The influence of $\mathrm{BR}$ on the expression of genes involved in cell cycle progression (c-myc, cyclin D1, cdc25A expression) and Cdk-2 activity was also examined since conflicting cell cycle signals could activate cell death processes.

\section{Results}

\section{Effect of BR on the proliferation of human ovarian adenocarcinoma $\mathrm{N} .1$ cells in vitro}

Cells $\left(2.4 \times 10^{4}\right)$ were seeded into 12 -well plates and cultured for 3 days. Then saline, 10 or $20 \mu \mathrm{M}$ BR was added, adherent cells were harvested every day for 6 days and the cell number was determined. Incubation of $\mathrm{N} .1$ cells with $10 \mu \mathrm{M}$ BR resulted in a significant reduction in proliferation rate compared to the logarithmic growth rate of control cells. Incubation of N.1 cells with $20 \mu \mathrm{M}$ BR resulted in a highly significant cytocidal effect $(P<0.0001)$ (Figure 1; Table 1). Elucidation of cytocidal effect of BR $(20 \mu \mathrm{M})$ was based on the fact that the number of cells present at $72 \mathrm{~h}$ was less than that observed at $48 \mathrm{~h}$ after treatment. Thus, it was of interest to determine cytotoxicity by a specific assay.

\section{Cytotoxicity of BR to human ovarian adenocarcinoma $\mathrm{N}$.1 cells}

Cells $\left(2.4 \times 10^{4}\right)$ were seeded into 12 -well plates and cultured for 3 days. Then saline, 10 or $20 \mu \mathrm{M}$ BR was added, cells were trypsinized, pooled with the cells floating in the culture medium and stained with $\mathrm{PI}$ to determine the percentage of dead cells. ${ }^{17-19}$ In control cells the rate of spontaneous dead cells was between $4.6-7.6 \%$ which increased to $14.1-$ $20.5 \%$ upon treatment with $10 \mu \mathrm{M}$ BR. The highest percentage of dead cells was observed after treatment with $20 \mu \mathrm{M}$ BR for $72 \mathrm{~h}(35.7 \%$; Figure $2 \mathrm{e}$ ) which is consistent with the decrease of cell number found in the cell proliferation assay (Figure 1; Table 1). Simultaneous treatment with the pan-caspase and apoptosis inhibitor Z-VAD-fmk together with $20 \mu \mathrm{M}$ BR repressed approximately $50 \%$ of the overall cytotoxic effect. Thus, it was of interest to further determine the type of cell death.

\section{BR induced apoptosis of $\mathrm{N} .1$ cells}

The nature of BR-induced cell death was determined first by examining DNA-integrity. Apoptotic DNA degradation characterized by oligonucleosomal fragmentation resulted after $72 \mathrm{~h}$ of BR treatment (Figure 2b) but was not observed when cells were treated with $10 \mu \mathrm{M}$ BR (data not shown). In addition, PARP was cleaved to the apoptosis specific $85 \mathrm{kDa}$ signature type fragment following treatment with $20 \mu \mathrm{M}$ BR for $72 \mathrm{~h}$ (Figure 2c and d) but not after exposure to $10 \mu \mathrm{M}$ BR. Apoptosis induced by $20 \mu \mathrm{M}$ BR treatment was dependent on caspase activity because the pan caspase inhibitor z-VAD-fmk abrogated PARP cleavage (Figure 2d), apoptosis (Figure 2f) and overall cytotoxicity (Figure 2e).

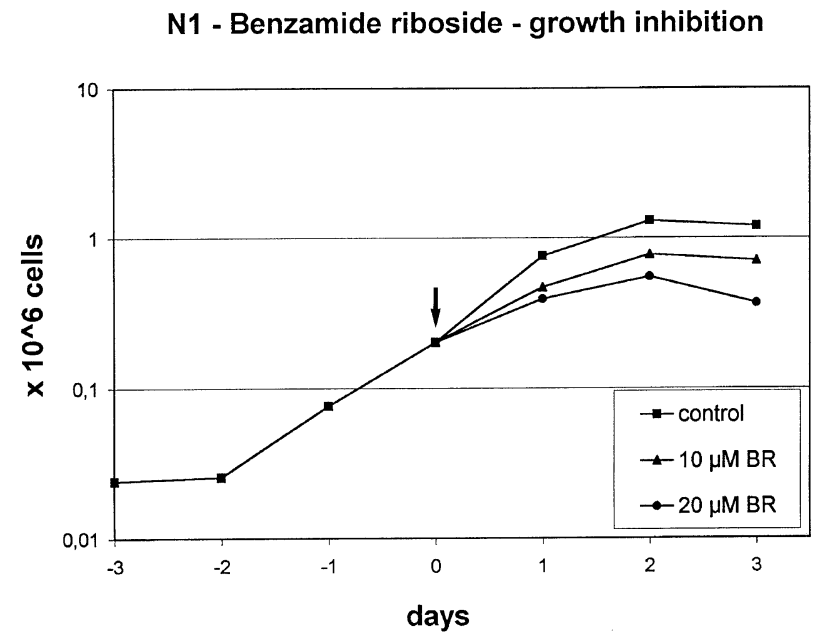

Figure 1 Inhibition of proliferation of N.1 cells after treatment with benzamide riboside (BR). For each time point, 12-well plates were seeded with $2.4 \times 10^{4}$ cells and allowed to grow for 3 days and then 10 or $20 \mu \mathrm{M}$ BR (indicated by an arrow, day 0) was added. One set of N.1 cells, treated with saline, served as control. Cells were detached from the wells with trypsin on days $-2,-1,0,1$, 2, 3 after saline or BR treatment and the cell number was determined. The abscissa shows the time in days of incubation and the ordinate shows the amount of cells per well. The results were from triplicate experiments

Table 1 Human ovarian carcinoma N.1 cell number before and after BR treatment

\begin{tabular}{|c|c|c|c|c|c|c|c|}
\hline Day & -3 & -2 & -1 & 0 & 1 & 2 & 3 \\
\hline Control & 24300 & 25800 & 76400 & 201900 & 750000 & 1292000 & 1192200 \\
\hline $10 \mu \mathrm{M} \mathrm{BR}$ & 24300 & 25800 & 76400 & 201900 & 465600 & 768000 & 697700 \\
\hline $20 \mu \mathrm{M}$ BR & 24300 & 25800 & 76400 & 201900 & 388500 & 546000 & 364200 \\
\hline
\end{tabular}

Seeding of N.1 cells into 12 well plates was performed on day -3 . Benzamide riboside (BR) (10 or $20 \mu \mathrm{M})$ was added on day 0 


\section{Dose-dependent BR mediated apoptosis}

To further elucidate the type of N.1 cell death, cells were incubated with 10 or $20 \mu \mathrm{M}$ BR and the cell morphology was analyzed by phase contrast microscopy (Figure 2a). A typical apoptotic phenotype was exhibited by N.1 cells at $72 \mathrm{~h}$ following treatment with 10 or $20 \mu \mathrm{M}$ BR (Figure 2a lower panel; arrows $(\rightarrow)$ point at cells undergoing apoptosis). a

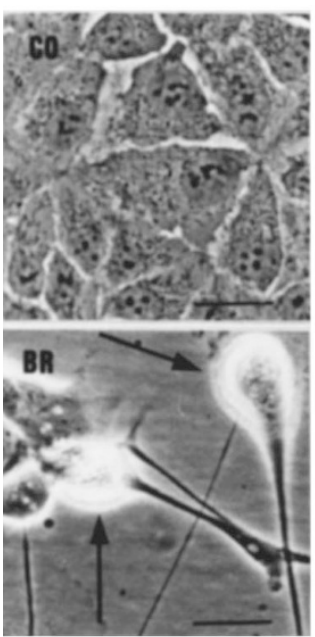

b
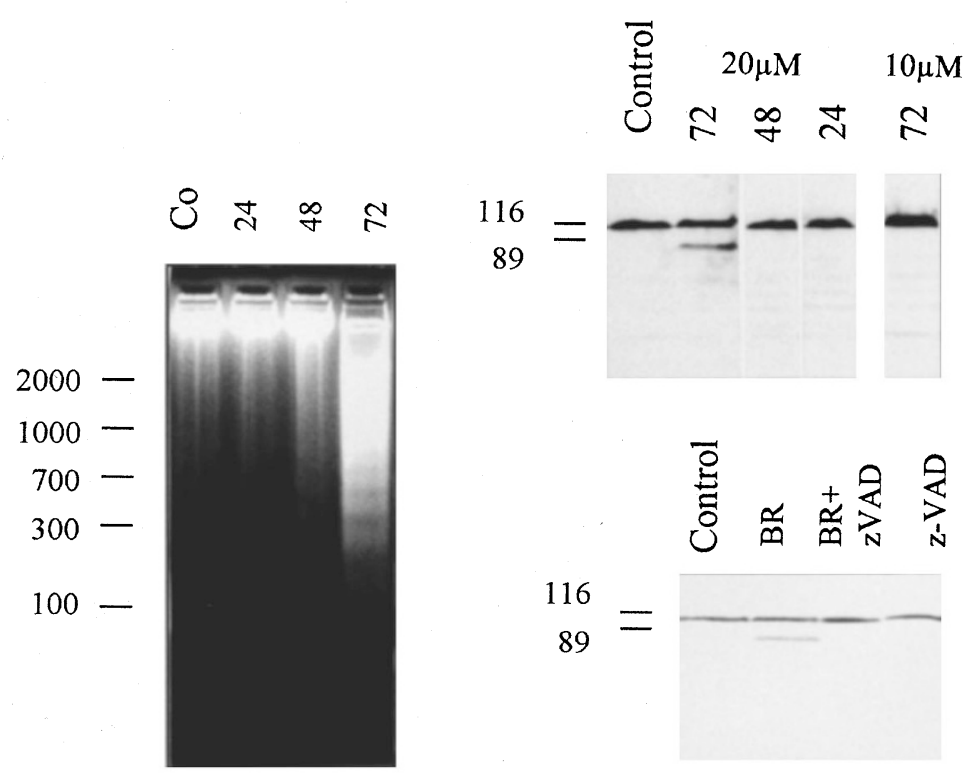

C

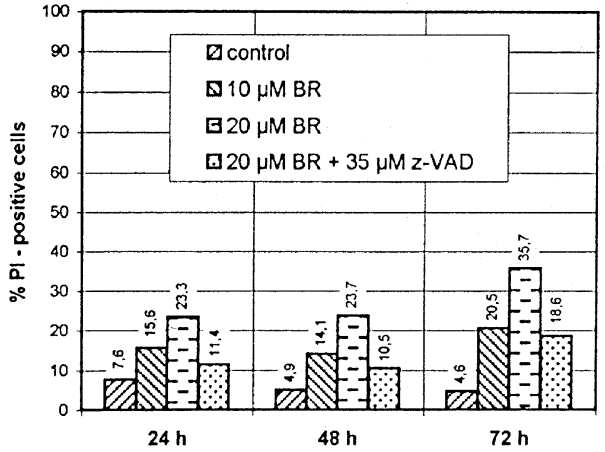

e

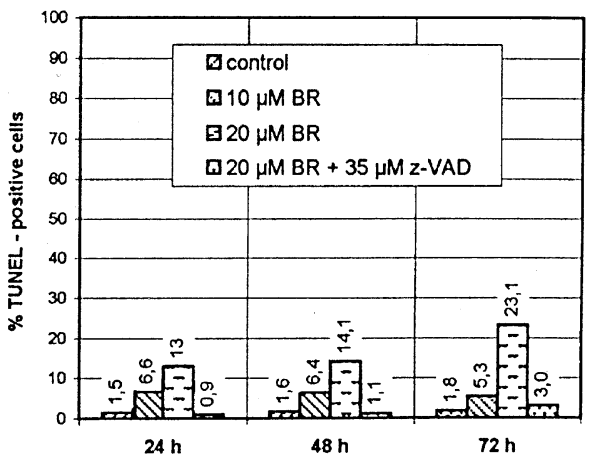

f

Figure 2 (a) Phase contrast light microscopy of N.1 cells following treatment. Cells were incubated with saline (panel A) or $20 \mu \mathrm{M}$ benzamide riboside (panel B) at $37^{\circ} \mathrm{C}$. Photographs were taken at 400 -fold magnification after $72 \mathrm{~h}$ of incubation. Arrows point at cells that show an apoptotic morphology typical for N. 1 cells. The scale bars at lower right corners: $25 \mu \mathrm{m}$. (b) Effect of benzamide riboside (BR) on DNA degradation. N.1 cells were incubated with saline (control) or $20 \mu \mathrm{M}$ BR for increasing periods of time (hours) and processed as detailed in Materials and Methods. Numbers on the left refer to base pairs determined by a DNA marker. (c) Degradation of PARP during benzamide riboside (BR) treatment. N.1 cells were treated with $20 \mu \mathrm{M} \mathrm{BR}$ for 24,48 and $72 \mathrm{~h}$ or with $10 \mu \mathrm{M} \mathrm{BR}$ for $72 \mathrm{~h}$, protein was extracted and separated on SDS-PAGE, transferred to nitrocellulose and immunoblotted with monoclonal anti-PARP antibody C-2-10 (right lane). The lane to the left shows an untreated control. The numbers to the left indicate kilo-Daltons. (d) Degradation of PARP during benzamide riboside (BR) treatment. N.1 cells were treated with $20 \mu \mathrm{M} \mathrm{BR}, 20 \mu \mathrm{M} \mathrm{BR}+35 \mu \mathrm{M}$ z-VAD-fmk, or $35 \mu \mathrm{M}$ z-VAD-fmk for $72 \mathrm{~h}$. Protein was extracted and separated on SDS-PAGE, transferred to nitrocellulose and immunoblotted with monoclonal anti-PARP antibody C-2-10 (right lane). The lane to the left shows an untreated control. The numbers to the left indicate kilo-Daltons. (e) Cytotoxicity of benzamide riboside (BR) to N.1 cells. For each time point, 12-well plates were seeded with $2.4 \times 10^{4}$ cells and allowed to grow for 3 days and then $10 \mu \mathrm{M} \mathrm{BR}, 20 \mu \mathrm{M}$ BR or $20 \mu \mathrm{M}$ BR+35 $\mu \mathrm{M}$ z-VAD-fmk (indicated by an arrow) was added. One set of N. 1 cells, treated with saline, served as control. Cells were detached from the flasks with trypsin and pooled with the cells floating in the cell culture supernatant on days $2,3,4,5$ and 6 following BR treatment: Cells were incubated with PI and examined under a microscope for nuclear PI-staining. The percentage of PI-positive cells (dead cells) was calculated. (f) Effect of benzamide riboside (BR) on the induction of apoptosis in N.1 cells. Cells were incubated with saline (control), $10 \mu \mathrm{M}, 20 \mu \mathrm{M} \mathrm{BR}$ or $20 \mu \mathrm{M} \mathrm{BR}+35 \mu \mathrm{M} \mathrm{z-}$ VAD-fmk for 24,48 and $72 \mathrm{~h}$ and apoptosis was determined by TUNEL assay. Numbers in the ordinate indicate the percentage of apoptotic cells obtained from the mean values of triplicate counts 
Similar morphological changes were noticeable when N.1 cells were exposed to unrelated apoptosis inducing agents such as ATRA, TNF-alpha and TNF-beta. ${ }^{15,16}$ Incubation of N.1 cells with either lower doses of benzamide riboside (1$5 \mu \mathrm{M})$ or with tiazofurin $(40 \mu \mathrm{M})$, a well characterized IMPDH inhibitor, did not induce programmed cell death (data not shown). It has been demonstrated that in human myelogenous leukemia K562 cells, TR is converted into its active metabolite, TAD, at a rate that is $50 \%$ less than that obtained with BR. ${ }^{12}$ Therefore, N. 1 cells were incubated with $40 \mu \mathrm{M}$ TR in order to compare it to the effect observed with $20 \mu \mathrm{M} B R$. Incubation with TR did not induce apoptosis in N.1 cells. Apoptosis exhibited by N.1 cells after 24,48 and $72 \mathrm{~h}$ exposure to BR was further confirmed by TUNEL-assay.
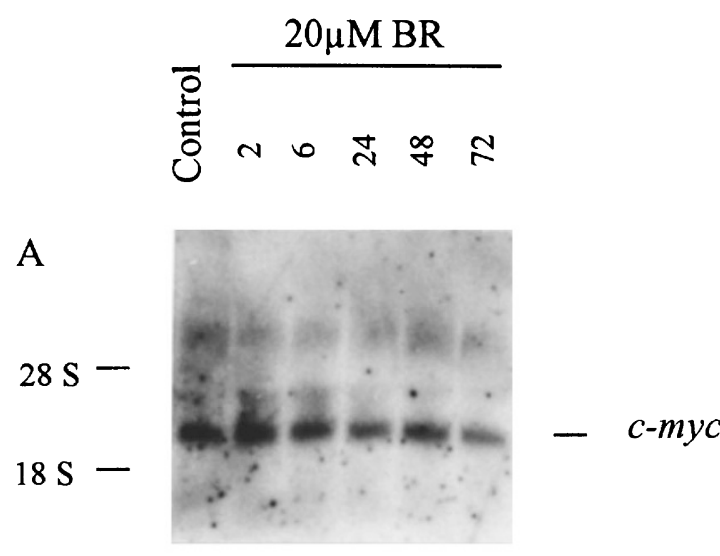

B

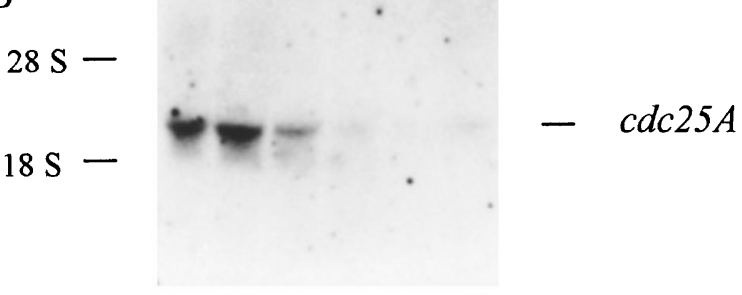

C
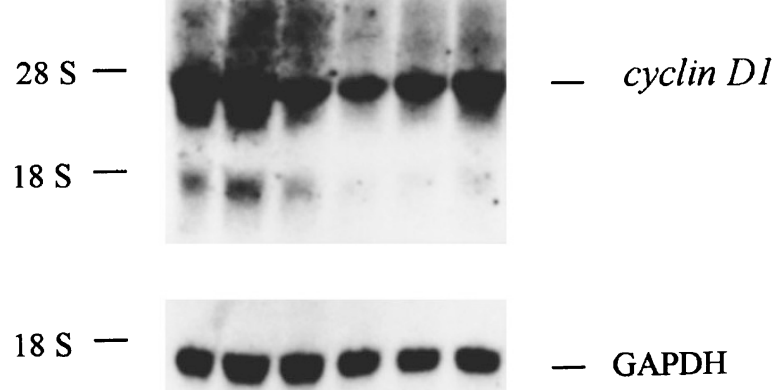

Figure 3 Kinetics of mRNA expression in cells treated with benzamide riboside (BR). N.1 cells were incubated with $20 \mu \mathrm{M}$ BR for the time periods indicated in the lanes. Control lane refers to cells treated with saline. Filters were hybridized against $c d c 25 A$ (panel B); stripped and rehybridized against c-myc (panel A); stripped and rehybridized against cyclin D1 (panel C); and stripped and rehybridized against GAPDH (bottom panel)
Control N.1 cells exhibited a spontaneous apoptosis rate of $1.5-1.8 \%$, and exposure of cells to $5 \mu \mathrm{M}$ BR did not significantly increase this rate $(2.9 \%$, data not shown). Treatment with $10 \mu \mathrm{M}$ BR enhanced the apoptotic response to $5.3-6.6 \%$ and treatment with $20 \mu \mathrm{M}$ to $23.1 \%$ at $72 \mathrm{~h}$ (Figure 2f). These values are statistically highly significant $(P<0.001)$. Combination of $z-V A D-f m k(35 \mu \mathrm{M})$ with $\mathrm{BR}$ $(20 \mu \mathrm{M})$ reduced the percentage of TUNEL-positive cells to control levels at all times investigated.

\section{Regulation of Cdc25A during apoptosis}

The four different methods of analysis shown above demonstrated that BR induced apoptosis in N.1 cells. Earlier investigations revealed that $\mathrm{N} .1$ cells undergo c-mycdependent apoptosis. ${ }^{15,20,21}$ Therefore, it was of interest to examine the influence of BR on the expression of: (i) the proto-oncogene, c-myc which induces cell-cycle progression from $G_{0}$ to $G_{i}{ }^{22}$ (ii) cdc25A, a $G_{1}$ specific cell cycle gene which also plays a role in apoptosis, ${ }^{23,24}$ and (iii) cyclin D1, another $\mathrm{G}_{1}$ cell cycle specific gene, which together with cdc25A is required for successful passage of cells from $G_{1}$ to $S$ phase. ${ }^{25,26}$ Incubation of N.1 cells with BR $(20 \mu \mathrm{M})$ did not modulate either c-myc mRNA expression (Figure 3; densitometric values are provided in Table 2) or the expression of cMyc protein as illustrated in Figure 4a. However, there was a transient down-regulation of cyclin D1 transcripts at $24 \mathrm{~h}$ to $45 \%$ of control levels (Figure 3 ; densitometric values are provided in Table 2) as well as of gas6 (data not shown). Cyclin D1 protein levels were expressed in accordance with the mRNA levels observed following $20 \mu \mathrm{M}$ BR treatment which underscores that Cdc25A down-regulation is specific to the induction of apoptosis (Figure 4a).

Incubation of N.1 cells with BR $(20 \mu \mathrm{M})$ resulted concurrently in down-regulation of cdc25A transcripts reaching a nadir at $48 \mathrm{~h}$ to $21 \%$ of control (a $79 \%$ reduction) in a time-dependent manner (Figure 3; densitometric values are provided in Table 2). Down-regulation of cdc25A transcripts was also reflected at the protein level. Treatment of $\mathrm{N} .1$ cells with $20 \mu \mathrm{M}$ BR resulted in a decrease in cdc25A protein at $48 \mathrm{~h}$ (Figure $4 \mathrm{a}$ ). The effect of treatment with $20 \mu \mathrm{M}$ BR on the activity of Cdk2, the target of cdc25A, was next examined. As anticipated, Cdk2 activity was inhibited when analyzed in an in vitro kinase assay in which histone $\mathrm{H} 1$ served as a substrate for Cdk2

Table 2 Densitometer evaluation of c-myc-mRNA, cdc25A-mRNA, and cyclinD1-mRNA expressions after treatment with benzamide riboside

\begin{tabular}{lcccccc}
\hline mRNA & Control & $\mathbf{2} \mathbf{h}$ & $\mathbf{6} \mathbf{h}$ & $\mathbf{2 4} \mathbf{h}$ & $\mathbf{4 8} \mathbf{h}$ & $\mathbf{7 2} \mathbf{h}$ \\
\hline c-myc & 100 & 107 & 103 & 92 & 99 & 73 \\
cdc25A & 100 & 91 & 64 & 32 & 21 & 27 \\
cyclin D1 & 100 & 99 & 59 & 45 & 81 & 90 \\
\hline
\end{tabular}

The intensities of the bands shown in Figure $3 a-c$ (Northern blot) were quantitated. The values are expressed as per cent of control following treatment of cells with $20 \mu \mathrm{M}$ benzamide riboside for $2,6,24,48$ and $72 \mathrm{~h}$. The densitometer readings of c-myc-mRNA, cdc25A-mRNA, and cyclinD1-mRNA expressions were normalized utilizing the densitometer readings of GAPDHmRNA expression which served as an internal control to indicate equal loading of the samples 
(Figure 4b). Therefore, BR treatment resulted in downregulation of cdc25A with concurrent inhibition of Cdk2activity, in spite of unchanged c-Myc expression.

As indicated earlier, incubation of N.1 cells with $40 \mu \mathrm{M}$ TR which did not induce apoptosis in these cells and only transiently suppressed cdc25A transcript after 6 and $24 \mathrm{~h}$

a
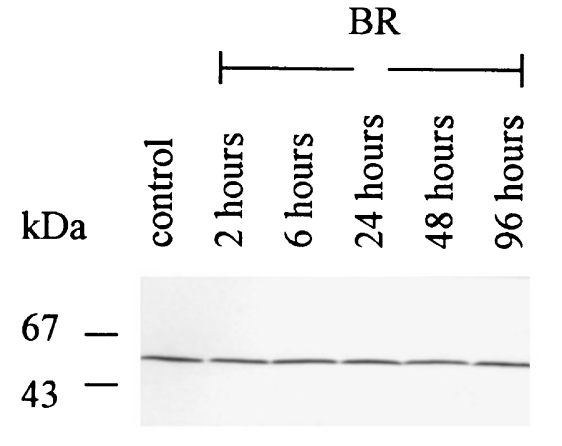

Myc

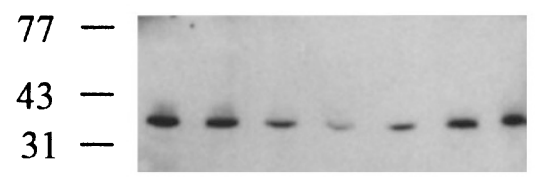

Cyclin DI

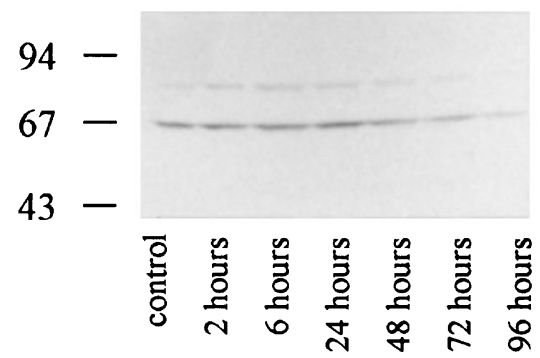

Cdc25A

b

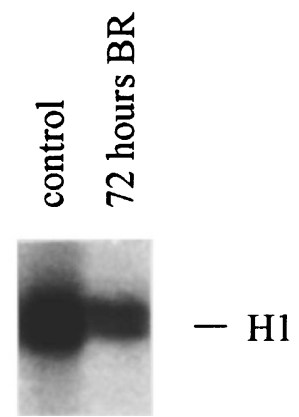

Figure 4 (a) Kinetic of c-Myc, cyclin D1 and Cdc25A protein expression in cells treated with benzamide riboside (BR). N.1 cells were incubated with $20 \mu \mathrm{M}$ BR for the time periods indicated in the lanes. Control lane refers to cells treated with saline. (b) Effect of benzamide riboside on Cdk2 immunocomplex formation. N.1 cells were exposed to $20 \mu \mathrm{M}$ benzamide riboside for $72 \mathrm{~h}$ (lane to the right). Lane 1 shows a control treated with saline. Protein was extracted as described in Materials and Methods. Cdk2 was immuno-precipitated with monoclonal anti-Cdk2 antibody. For the kinase reaction and in presence of ${ }^{32} \mathrm{P} \gamma \mathrm{ATP}$ histone $\mathrm{H} 1$ was used as a target. The reaction was terminated by boiling and samples were subjected to SDS-PAGE. Gels were dried and exposed to X-ray films at $-80^{\circ} \mathrm{C}$ exposure (Figure 5) without affecting Cdc25A protein level (data not shown).

\section{Discussion}

Four different methods were employed to demonstrate second mechanism of BR action, which has previously been shown to be an inhibitor of IMP dehydrogenase, and was now shown to induce apoptosis in human ovarian adenocarcinoma $\mathrm{N} .1$ cells. Although treatment of $\mathrm{N} .1$ cells with $10 \mu \mathrm{M}$ BR rendered about $6 \%$ of TUNEL-positive cells, no PARPcleavage or oligosomal DNA fragmentation was detected under these conditions which suggests that these methods of analysis are less sensitive than TUNEL assay or that other caspases, perhaps different from caspase 3, play a major role in BR-induced apoptosis of N.1 cells. The overall cytotoxic effect of $20 \mu \mathrm{M}$ BR after $72 \mathrm{~h}$ (35.7\%; determined by PIstaining) could only be in part ascribed to apoptosis $(23.1 \%$; determined by TUNEL assay), therefore, $12.6 \%$ (calculated) of the remaining cells succumbed to non-apoptotic cell death.

Strikingly, BR triggered apoptosis in N.1 cells despite the presence of $10 \%$ FCS (fetal calf serum). All other agents examined so far (ATRA, TNF-alpha, TNF-beta and trimidox) induced apoptosis only in the presence of low serum concentration. ${ }^{15,20}$ This action suggests that BR induced apoptosis in spite of the presence of factors in the serum that support cell survival.

Another analogous agent, TR, which was shown to inhibit IMPDH activity similar to that of $\mathrm{BR},{ }^{11}$ was included for comparison in the examination of induction of apoptosis in N.1 cells. However, no apoptosis of N.1 cells was observed following TR treatment. Therefore, BR may exert a unique apoptosis inducing activity on N.1 cells.

It was shown that apoptosis induction by serum withdrawal in IL-3 in rodent fibroblasts, ${ }^{27,28}$ and by TNF in HeLa cells depended on c-Myc expression. ${ }^{29}$ It was

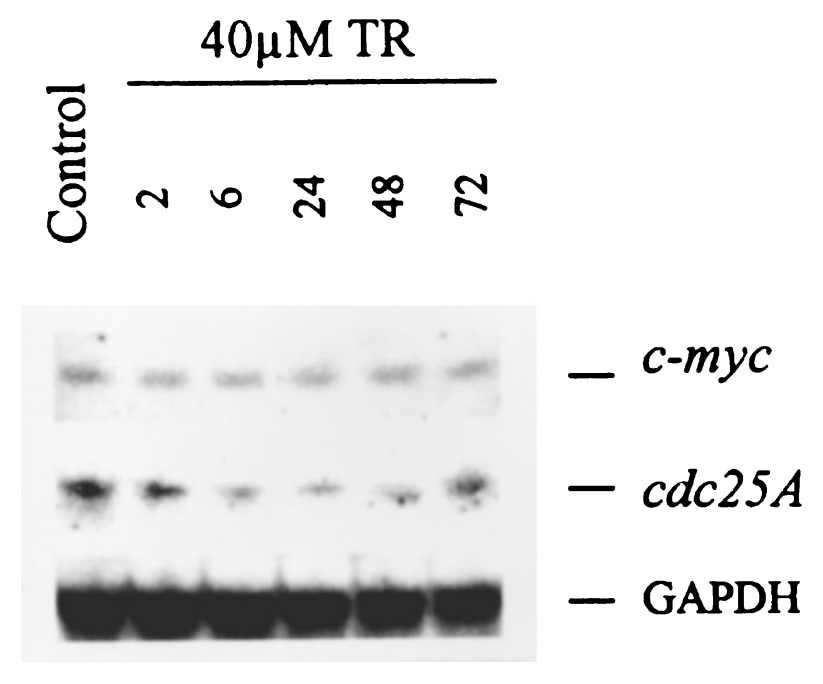

Figure 5 Kinetics of mRNA expression in cells treated with tiazofurin (TR). $\mathrm{N} 1$ cells were incubated with $40 \mu \mathrm{M}$ TR for the time periods indicated in the lanes. Control lane refers to cells treated with saline. Filters were hybridized against $c d c 25 A$; stripped and rehybridized against c-myc; and stripped and rehybridized against GAPDH 
recently shown that $\mathrm{N} .1$ cells underwent c-myc-dependent cell death. ${ }^{15,20,21}$ Apoptosis-inducing concentrations of BR, however, did not interfere with the constitutive expression of c-Myc in this fast growing human ovarian carcinoma N.1 cell line.

It has been shown that the transcription factor c-Myc directly regulated cdc25A expression and that apoptosis induced by conditional ectopic Myc activation depended entirely on Cdc25A expression. ${ }^{24}$ Our results with N.1 cells demonstrate that during $\mathrm{BR}$-induced apoptosis, constitutive c-Myc expression was not altered, but cdc25A transcript was down-regulated, thereby resulting in the reduction in Cdc25A protein levels. In concurrence with the present results, apoptosis in N.1 cells was induced by TNF in spite of constitutive c-Myc expression, with a concurrent decrease of cdc25A transcript and reduced Cdc25A protein levels. ${ }^{20}$ Therefore, in this instance apoptosis was independent of Cdc25A in N.1 cells. In concurrence with our findings, recent studies have demonstrated that c-Myc induction did not regulate cdc25A expression in rat fibroblasts. ${ }^{30-32}$

In a preliminary study with rat fibroblast cells, apoptosis was triggered by serum removal that was accompanied by down-regulation of cdc25A. Supplementation with PDGF reestablished cdc25A expression and prevented apoptosis (unpublished observations). These studies reiterate that cdc25A may have an interesting role to play in apoptosis and survival.

The analysis of c-myc and cdc25A expression during treatment with TR (another related IMPDH inhibitor) that did not induce apoptosis revealed a transient downregulation of cdc25A transcript levels that recovered after $48 \mathrm{~h}$ and that the expression of Cdc25A protein was unaffected. Therefore, BR exhibits dual mechanisms of action, one by inhibiting IMPDH and the other by inducing apoptosis, in addition having a selective action on cdc25A expression.

Raf1 was shown to phosphorylate Cdc25A to activate it. $^{33}$ This interaction seems to be mediated by members of the 14-3-3 family of proteins. ${ }^{34}$ Activated Raf was shown to be important for the survival of IL-3 dependent hematopoietic cells; ${ }^{35,36}$ increased the survival response in cells exposed to ionizing radiation; ${ }^{37,38}$ mediated insulin-, NGFand PDGF-dependent growth and survival signals; ${ }^{39}$ and protected cells from c-Myc-induced apoptosis in v-abl transformed cells. ${ }^{40}$

Moreover, an anti-apoptotic effect mediated by Cdc25A in Rat1MycER cells was demonstrated, wherein serum induced cell growth was not sufficient to generate full expression of Cdk2 activity because cdc25A phosphatase activity was rate limiting and was incompletely expressed in the absence of external growth factors. ${ }^{41}$ Since Mycdependent apoptosis in Rat1MycER cells was triggered by serum deprivation, ${ }^{42} \mathrm{Cdc} 25 \mathrm{~A}$ activity seems to promote cell survival.

Activation of c-Myc can lead to either proliferation or apoptosis based on the presence of survival signals. ${ }^{27,28}$ Therefore, extracellular factors which promote growth and/ or survival might be mediated across Raf and cdc25A to the cell cycle machinery. ${ }^{33}$
It was suggested that consistent expression of c-Myc in N.1 cells promotes cell cycle initiation from $G_{0}$ to $G_{1}$ phase, ${ }^{22,27,28,30,31,43}$ whereas concurrent down-regulation of cdc25A (such as with BR) might interrupt further cell cycle progression. ${ }^{25,44,45}$ In our studies, cdc25A expression correlated with survival, and down-regulation of cdc25A preceded apoptosis. An anticipated, cdc25A down-regulation paralleled with the inactivation of Cdk2.

BR induced active cell death in spite of the presence of serum. This activity suggests that BR might have interrupted anti-apoptotic signals from serum factors. This is because a functional relation between cell survival, Raf1 and the cdc25A proto-oncogene has been demonstrated. ${ }^{23,24,35-40}$ Tilting a balance between factors, which contribute to cell cycle start signals and those which contribute to cell cycle progression, might trigger apoptosis.

During BR treatment, gas6 (a gene specifically upregulated during growth arrest) ${ }^{45}$ and c-myc was expressed at unchanged levels, whereas cyclin D1 mRNA and protein levels became transiently inhibited after $24 \mathrm{~h}$. Therefore cdc25A repression was specific to the induction of apoptosis and not due to a cell cycle arrest in $G_{0}$ phase. $^{22,43,46-48}$

This is the first report demonstrating the induction of apoptosis in cancer cells by BR, a new C-nucleoside, with a concurrent down-regulation of cdc25A expression. The exact role of cdc25A in apoptosis and survival will be addressed in future studies.

\section{Materials and Methods}

\section{Materials}

BR was synthesized as described. ${ }^{9}$ Monoclonal anti-Myc antibodies were purchased from Genosys (UK), and polyclonal anti-Cdc25A antibodies and monoclonal anti-cyclin D1 antibodies were from Santa Cruz (CA, USA). All other chemicals of highest quality were purchased from Sigma Chemical Co., St. Louis (MO, USA). Z-VAD-fmk was from Alexis Biochemicals, San Diego (CA, USA). The cDNAs of cdc25A were kindly provided by Dr. David Beach, Cold Spring Harbor (NY, USA); cyclin D1 by Dr. Hannes Hofmann, IMP, Vienna, Austria; c-myc by Dr. Rainer deMartin, University of Vienna, Austria; and GAPDH by Dr. Paul Amstad, University of Maryland (College Park, MD, USA).

\section{Cell culture}

The monoclonal human ovarian adenocarcinoma N.1 cell line is a derivative of the heterogenous $\mathrm{HOC}-7$ cell line which was cultured in MEM supplemented with $10 \%$ FCS (GIBCO, Paisley, UK) at $37^{\circ} \mathrm{C}$ in a humidified atmosphere of $95 \%$ air and $5 \% \mathrm{CO}_{2}$.

\section{Benzamide riboside treatment}

Human ovarian adenocarcinoma N.1 cells were cultured in 12-well plates or T-25 plates (Falcon) and after reaching $70 \%$ confluence, cells were treated with either saline or BR $(1-20 \mu \mathrm{M})$ for periods up to $72 \mathrm{~h}$.

\section{Determination of cell proliferation}

Human ovarian adenocarcinoma N.1 cells were seeded at a density of $2.4 \times 10^{4}$ cells into 12 -well plates and allowed to grow into a 
logarithmic phase before the addition of BR (day 3 after seeding). To determine the cell number the culture medium was aspirated, cells were trypsinized and counted under a Zeiss Axiovert 35 inverse microscope.

\section{Determination of cytotoxicity}

Human ovarian adenocarcinoma N.1 cells were seeded at a density of $2.4 \times 10^{4}$ cells into 12-well plates and allowed to grow into a logarithmic phase before the addition of BR (day 3 after seeding). To determine the cytotoxic activity of BR, cells were trypsinized, pooled with the cells floating in the cell culture supernatant, stained with $\mathrm{PI}$, counted under a microscope and the percentage of PI-positive cells was calculated. ${ }^{17-19}$

\section{Northern blot analysis}

Human ovarian adenocarcinoma N.1 cells were incubated with BR as described above. Incubations were terminated by removing drug containing medium. The cells were washed twice with ice cold PBS, and subsequently lysed with RNAzol (BioTex, Houston, TX, USA). Total RNA (30 $\mu \mathrm{g} /$ lane) was separated on $1 \%$ agarose gels containing formaldehyde and transferred to Millipore $S$ membranes (Millipore, Bedford, MA, USA) by the capillary method. Biotinylated probes were allowed to hybridize to filter-bound RNA at $67^{\circ} \mathrm{C}$ overnight. Biotinylation procedures and filter processing were conducted as described. ${ }^{49}$ Filters were then exposed to Kodak X-ray films (Rochester, NY, USA).

\section{DNA analysis}

Human ovarian adenocarcinoma N.1 cells were treated with saline or $\mathrm{BR}$ as described above. Supernatant cells were centrifuged and lysed in $0.4 \mathrm{ml}$ buffer containing $50 \mathrm{mM}$ Tris- $\mathrm{HCl}, \mathrm{pH} 8.0 ; 10 \mathrm{mM}$ EDTA; and $0.5 \%$ sodium lauryl sarcosine. The adherent cells ( $100 \%$ in controls) were lysed in the same buffer $(1.2 \mathrm{ml})$. Aliquots of $0.4 \mathrm{ml}$ lysates from adherent and detached cells were treated with $2 \mu$ RNAse A (11 U/l, USB, Cleveland, $\mathrm{OH}, \mathrm{USA}$ ) for $1 \mathrm{~h}$ at $37^{\circ} \mathrm{C}$, followed by the addition of $10 \mu$ of proteinase $\mathrm{K}(15 \mathrm{mg} / \mathrm{ml}$; Boehringer Mannheim, Germany) and further incubation at $50^{\circ} \mathrm{C}$ for $3 \mathrm{~h}$. An equal amount of phenol:chloroform: isoamyl alcohol $(25: 24: 1)$ was added and DNA was extracted by gentle treatment (wide-bore pipettes were used without vortexing). After two washes with chloroform isoamyl alcohol (24:1), DNA was precipitated with ethanol, and resuspended in $30 \mu \mathrm{l}$ TE buffer (10 mM Tris-HCl, pH 7.5 with $1 \mathrm{mM}$ EDTA) containing $2 \mu \mathrm{l}$ RNAse (2 U/I). The lysates derived from adherent and detached cells were pooled, the DNA content was quantitated and equal amounts of DNA were subjected to separation on $2 \%$ agarose gels. ${ }^{15}$

\section{TUNEL assay}

Cells were exposed to saline, 10 or $20 \mu \mathrm{M}$ BR for $72 \mathrm{~h}$. Floating cells were collected and pooled with the trypsinized monolayer cells. Trypsin activity was stopped by the addition of serum. Aliquots of pooled samples were subjected to cytospin onto siliconised glass plates (2 min at $70 \times g)$, air dried, fixed with $4 \%$ paraformaldehyde and further processed as described in the instructions of the In Situ Cell Death detection Kit manual (Boehringer, Mannheim, Germany). After the reaction with terminal deoxynucleotidyl transferase, total cell number was first determined by phase contrast microscopy. Then fluorescing cells were counted within the same frame by utilizing fluorescence microscopy. From these counts the percentage of apoptotic cells was calculated.

\section{Western blot analysis}

Human ovarian adenocarcinoma N.1 cells were treated with BR or saline, washed twice with ice cold PBS, and then lysed with SDS sample buffer ( $3 \%$ SDS, 10\% glycerol, $36 \mathrm{mM}$ DTT, $18.5 \mathrm{mM}$ EDTA, and $25 \mathrm{mM}$ Tris- $\mathrm{HCl} \mathrm{pH} 6.8$ ). Cells were sonicated and protein concentrations were quantitated by dot-metric analysis (Novus Molecular, San Diego, CA, USA). Equal amounts of protein (40$100 \mu \mathrm{g} / \mathrm{lane})$ were loaded onto SDS-polyacrylamide gels $(10 \%$ acrylamide/bisacrylamide) separated at $80 \mathrm{~V}$ (constant) and electrophoretically transferred to 0.45 nitrocellulose membranes (Schleicher Schuell, Dassel, Germany). Filters were blocked with $5 \%$ skimmed milk, $0.5 \%$ Tween 20 , followed by incubation overnight at $4{ }^{\circ} \mathrm{C}$ with the first antibody (monoclonal anti-Myc antibody at a 1:200 dilution; monoclonal anti cyclin D1 antibody at a 1:1000 dilution; monoclonal anti-PARP C-2-10 antibody at a 1:5000 dilution; and polyclonal anti Cdc25A antibody at a 1:20000 dilution). Secondary antibody reaction was carried out by incubating filters with horseradish peroxidase conjugated with sheep anti-mouse antibody (Amersham International, UK) at a 1:5000 dilution for $2 \mathrm{~h}$ at room temperature. Signal was developed using the ECL kit according to the instructions of the manufacturer (Amersham International, UK).

\section{Laser scanning analysis}

The images of Northern blots were developed on X-ray films and scanned by a laser dot beam ( $1 \mathrm{~mm}$ diameter) across the length axis of the individual mRNA bands. The peak areas underneath the plotted curves were excised and weighed on an analytical balance. The corresponding peak values of the GAPDH mRNA bands (internal loading standard) were utilized for factor-correction of the peak values of the c-myc-, cdc25A- and cyclin D1 mRNA bands.

\section{Kinase assay}

Protein extracts were prepared in buffer containing $20 \mathrm{mM}$ HEPES $\mathrm{pH} 7.9,0.4 \mathrm{M} \mathrm{NaCl}, 2.5 \%$ glycerol, $1 \mathrm{mM}$ EDTA, 1 mM phenylmethylsulfonyl fluoride, $0.5 \mathrm{mM} \mathrm{NaF}, 0.5 \mathrm{mM} \mathrm{Na}_{3} \mathrm{VO}_{4}, 0.02 \mu \mathrm{g} / \mathrm{ml}$ leupeptin, $0.02 \mu \mathrm{g} / \mathrm{ml}$ aprotinin, $0.003 \mu \mathrm{g} / \mathrm{ml}$ benzamidine hydrochloride, $0.1 \mu \mathrm{g} /$ $\mathrm{ml}$ trypsin inhibitor and $0.5 \mathrm{mM}$ DTT. After a freeze-thaw cycle in liquid nitrogen, cellular debris was precipitated by centrifugation and supernatants were stored at $-70^{\circ} \mathrm{C} .^{32}$ Protein concentrations were determined using the BioRad protein reagent with bovine serum albumin, Fraction V, as standard. Cdk immunoprecipitation and Cdkanalysis were performed as cited. ${ }^{50}$ Anti-Cdk2 antibody (St. Cruz) was coupled to protein G-Sepharose beads and incubated with $30 \mu \mathrm{g}$ protein extract for several hours at $4{ }^{\circ} \mathrm{C}$. For protein kinase assay these beads were resolved in a mixture containing $50 \mathrm{mM}$ Tris $\mathrm{pH} 7.4$, $10 \mathrm{mM} \mathrm{MgCl}_{2}, 1 \mathrm{mM}$ DTT, $0.2 \mathrm{mM} \mathrm{PMSF}, 1 \mathrm{mM} \mathrm{NaF}, 80 \mathrm{mM}$ radioactive ATP and $1 \mu \mathrm{g}$ histone $\mathrm{H} 1$. After incubation at $37^{\circ} \mathrm{C}$ for $30 \mathrm{~min}$, proteins were separated by electrophoresis on a $12 \%$ SDSpolyacrylamide gel. The gel was dried and exposed to X-ray film at $-80^{\circ} \mathrm{C}$.

\section{Statistical analyses}

Statistical differences were computed with the SPSS software. Results are given as mean \pm standard deviation (S.D.). Means were compared by using paired samples $t$-test or by one way analysis of variance using Bonferron's post hoc range test for multiple comparisons, as appropriate. A $P$ value of $<0.05$ was considered significant. 


\section{Acknowledgements}

We thank Mariola Zukowski for the excellent technical assistance in the chemical synthesis and Anton Jaeger for helping with the figures. Supported in part by Jubilaeumsfonds der Oesterreichischen Nationalbank, Grant No. 5267, the Hochschuljubiläumsstiftung and the Fonds des Bürgermeisters der Stadt Wien (to T.Szekeres), by the Association for International Cancer Research-grant No. 97-12, the Herzfelder'sche Familienstiftung, the Kommission Onkologie and the Anton Dreher Gedächtnisstiftung (to G.Krupitza), by the Theodor Koerner Stiftungspreis (to G.Fuhrmann) and by a research fellowship of the Medical Faculty of the University of Vienna (to M.Grusch).

\section{References}

1. Jackson RC, Weber G and Morris HP (1975) IMP dehydrogenase: an enzyme linked with proliferation and malignancy. Nature 256: $331-333$

2. Weber G (1983) Biochemical strategy of cancer cells and design of chemotherapy, G.H.A. Clowes Memorial Lecture. Cancer Res. 43: 3466-3492

3. Jayaram HN, Zhen W and Gharehbaghi K (1993) Biochemical consequences of resistance to tiazofurin in human myelogenous leukemic K562 cells. Cancer Res. 53: $2344-2348$

4. Knight RD, Magnum J, Lucas DI, Cooney DA, Khan EC and Wright DG (1987) Inosine monophosphate dehydrogenase and myeloid cell development. Blood 69: 634-639

5. Jayaram HN, Dion RL, Glazer RI, Johns DG, Robins RK, Srivastava PC and Cooney DA (1982) Initial studies on the mechanism of action of a new oncolytic thiazole nucleoside, 2- $\beta$-D-ribofuranosylthiazole-4-carboxamide (NSC 286193). Biochem. Pharmacol. 31: 2371-2380

6. Tricot GJ, Jayaram HN, Lapis E, Natsumeda Y, Nichols CR, Kneebone P, Heerema N, Weber $G$ and Hoffman R (1989) Biochemically directed therapy of leukemia with tiazofurin, a selective blocker of inosine 5'-phosphate dehydrogenase activity. Cancer Res. 49: 3696-3701

7. Jayaram HN, Lapis E, Tricot G, Kneebone P, Paulik E, Zhen W, Engeler GP Hoffman R and Weber G (1992) Clinical pharmacokinetic study of tiazofurin administered as a 1-hour infusion. Int. J. Cancer 51: 182-188

8. Wright DG, Boosalis MS, Waraska K, Oshry LJ, Weeintraub LR and Vosburgh E (1996) Tiazofurin effects on IMP-dehydrogenase activity and expression in the leukemia cells of patients with CML blast crisis. Anticancer Res. 16:3349-3354

9. Krohn K, Heins H and Wielckens K (1992) Synthesis and cytotoxic activity of Cglycosidic nicotinamide riboside analogues. J. Med. Chem. 35: 511-517

10. Jayaram HN, Gharehbaghi K, Jayaram NH, Rieser J, Krohn K and Paull KD (1992) Cytotoxicity of a new IMP dehydrogenase inhibitor, benzamide riboside, to human myelogenous leukemia K562 cells. Biochem. Biophys. Res. Commun. 186: $1600-1606$

11. Gharehbaghi K, Sreenath A, Hao Z, Paull KD, Szekeres T, Cooney DA, Krohn K and Jayaram HN (1994) Comparison of biochemical parameters of benzamide riboside, a new inhibitor of IMP dehydrogenase, with tiazofurin and selenazofurin. Biochem. Pharmacol. 48: 1413-1419

12. GharehbaghiK, Paull KD, Kelley JA, Barchi JJ, Marquez VE, Cooney DA, Monks A, Scudiero D, Krohn Kand Jayaram HN (1994) Cytotoxicity and characterization of an active metabolite of benzamide riboside, a novel inhibitor of IMP dehydrogenase. Int. J. Cancer 56: 892-899

13. Cooney DA, Jayaram HN, Gebeyehu G, Betts CR, Kelley JA, Marquez VE and Johns DG (1982) The conversion of 2- $\beta$-D-ribofuranosylthiazole-4-carboxamide to an analog of NAD with potent IMP dehydrogenase-inhibitory properties. Biochem. Pharmacol. 31: 2133-2136

14. Grunt T, Dittrich E, Somay C, Wagner T and Dittrich C (1991) Separation of clonogenic and differentiated cell phenotypes of ovarian cancer cells HOC-7 by discontinuous density gradient centrifugation. Cancer Lett. 58:7-16

15. Krupitza G, Hulla W, Harant H, DittrichE, Kallay E, Huber H, Grunt Tand Dittrich C (1995) Retinoic acid induced death of ovarian carcinoma cells correlates with cmyc stimulation. Int. J. Cancer 61:649-657

16. Krupitza G, Harant H, Dittrich E, Szekeres T, Huber H and Dittrich C (1995) Sodium butyrate inhibits c-myc splicing and interferes with signal transduction in ovarian carcinoma cells. Carcinogenesis 16: 1199-1205
17. Vitale M,Zamai L, Mazzotti G, Cataldi A and FalcieriE (1993) Differential kinetics of propidium iodide uptake in apoptotic and necrotic thymocytes. Histochemistry 100: $223-229$

18. Ankarcrona M, Dypbukt JM, Bonfoco E, Zhivotovsky B, Orrenius S, Lipton SA and Nicotera P (1995) Glutamate-induced neuronal cell death: a succession of necrosis or apoptosis depending on mitochondrial function. Neuron 15: $961-$ 973

19. Niocotera P and Leist M (1997) Energy supply and the shape of death in neurons and lymphoid cells. Cell Death Differ. 4: 435-442

20. Krupitza G, Grusch M, Braun K, Fuhrmann G, Steinbrugger R, Hulla W, Simonitsch I, Chott A and Hengstschläger M (1998) TNF-mediated cell death is independent of Cdc25A. Cell Death Differ. 5: 758-764

21. Simonitsch I and Krupitza G (1998) Autocrine self elimination of cultured ovarian cancer cells by TNFa. Br. J. Cancer 78: 862-870

22. Marcu KB, Bossone SA and Patel AJ (1992) Myc function and regulation. Ann. Rev. Biochem. 61: 809-860

23. Galaktionov K, Lee AK, Eckstein J, Draetta G, Meckler J, Loda M and Beach D (1995) Cdc25 Phosphatases as potential human oncogenes. Science 269: $1575-1577$

24. Galakationov K, Chen X and Beach D (1996) Cdc25 cell-cycle phosphatase as a target of c-myc. Nature 382: 511-517

25. Jinno S, Suto $K$, Nagata A, Igarashi $M$, Kanaoka $Y$, Nojima $H$ and Okayama $H$ (1994) Cdc25A is a novel phosphatase functioning early in the cell cycle. EMBO J. 13: $1549-1556$

26. MacLachlan TK, Sang N and Giordano A (1995) Cyclins, cyclin dependent kinases and cdk inhibitors: implications in the cell cycle control and cancer. Crit. Rev. Eukaryot. Gene Express 5: 127-156

27. Askew DS, Ashmun RC, Simmons BC and Cleveland JL (1991) Constitutive cmyc expression in an IL-3 dependent myeloid cell line suppresses cell cycle arrest and accelerates apoptosis. Oncogene 6: 1915-1922

28. Evan G, Wyllie A, Gilbert C, Littlewood T, Land H, Brooks M, Waters C and Hancock D (1992) Induction of apoptosis in fibroblasts by c-myc protein. Cell 69: $119-128$

29. Klefstrom J, Vastrik I, Saksela E, Valle J, Eilers M and Alitalo K (1994) C-Myc induces cellular susceptibility to the cytotoxic action of TNF-alpha. EMBO J. 13: $5442-5450$

30. Vlach J, HenneckeS, Alevizopoulos K, Conti D and Amati B (1996) Growth arrest by the cyclin dependent kinase inhibitor p27 kip1 is abrogated by c-myc. EMBOJ. 15: 6595-6604

31. Perez-Roger I, Solomon D, Sewing A and Land H (1997) Myc activation of cyclin E/Cdk-2 kinase involves induction of cyclin E gene transcription and inhibition of p27 Kip1 binding to newly formed complexes. Oncogene 14: 2373-2381

32. Pusch O, Bernaschek G, Eilers M and Hengstschläger M (1997) Activation of cMyc uncouples DNA-replication from activation of G1-cyclin dependent kinases. Oncogene 15: 649-656

33. Galaktionov K, Jessus C and Beach D (1995) Raf interaction with Cdc25A phosphatase ties mitogenic signal transduction to cell cycle activation. Genes Dev. 9: $1046-1058$

34. Conklin D, Galaktionov K and Beach D (1995) 14-3-3 Proteins associate with Cdc25 phosphatases. Proc. Natl. Acad. Sci. USA 92: 7892-7896

35. Cleveland J, Troppmair J, Packham G, Askew D, Lloyd P, Gonzales-Garcia M, Nunez G, Ihle J and Rapp U (1994) v-Raf suppresses apoptosis and promotes growth of IL-3 dependent myeloid cells. Oncogene 9: 2217-2226

36. Kinoshita T, Shirouzu M, Kamyia A, Hashimoto K, Yokoyama S and Myijima A (1997) Paf/MAPK and rapamycin-sensitive pathways mediated the antiapoptotic function of p21Ras in IL-3 dependent hematopoietic cells. Oncogene 7: $619-627$

37. Canman C, Gilmer T, Coutts S and Kastan M (1995) Growth factor modulation of p53-mediated growth arrest versus apoptosis. Genes Dev. 9: 600-611

38. Kasid U, Suy S, Dent P, Ray S, Whiteside T and Sturgill T (1996) Activation of raf by ionizing radiation. Nature $382: 813-816$

39. Williams N and Roberts T (1994) Signal transduction pathways involving the raf proto-oncogene. Cancer Metastasis Rev. 13: 105-116

40. Weissinger E, Eissner G, Grammar C, Fackler S, Haefner B, Yoon L, Lu K, Bazarov A, Sedivy J, Mischak H and Kolch W (1997) Inhibition of the Raf1 kinase by cAMP agonists causes apoptosis of v-abltransformed cells. Mol. Cell. Biol. 17: $3229-3241$ 
41. Steiner P, Phillip A, Godden-Kent D, Pagano M, Mittnacht S, Bartek J and Eilers $M$ (1995) Identification of a Myc-dependent step during the formation of active $G 1$ cyclin-cdk complexes. EMBO J. 14: 4814-4826

42. Lenahan M and Ozer H (1996) Induction of c-myc mediated apoptosis in SV40transformed rat fibroblasts. Oncogene 12: 1847-1854

43. Amati B, Alevizopoulos K and Vlach J (1975) Myc and the cell cycle. Frontiers Biosci. 3: 250-268

44. Spitovsky D, Jansen-Durr P, Karsenti E and Hoffman I (1996) S-phase induction by adenovirus $\mathrm{E} 1 \mathrm{~A}$ requires activation of cdc25A tyrosine phosphatase. Oncogene 12: 2549-2554

45. Tiefenbrun N, Melamed D, Levy N, Resnitzky D, Hoffman I, Reed S and Kimchi A (1996) Alpha interferon suppresses the cyclin D3 and cdc25A genes, leading to reversible $\mathrm{G}_{0}$-like arrest. Mol. Cell. Biol. 16: 3934-3944
46. Schneider C, King $L$ and Philipson $L$ (1988) Genes specifically expressed at growth arrest of mammalian cells. Cell 54: 787-793

47. Motokura T and Arnold A (1993) Cyclins and oncogenesis. Biochem. Biophys. Acta 1155: 63-78

48. Draetta G (1994) Mammalian G1 cyclins. Curr. Opin. Cell Biol. 6: 842-846

49. Krupitza G, Fritsche R, Dittrich E, Harant $H$, Huber $H$, Grunt $T$ and Dittrich $\mathrm{C}$ (1995) Macrophage colony-stimulating factor is expressed by an ovarian carcinoma subline and stimulates the c-myc proto-oncogene. Br. J. Cancer 72: $35-40$

50. Soucek T, Pusch $O$, Hengstschläger-Ottnad E, Adams $P$ and Hengstschläger $M$ (1997) Deregulated expression of E2F-1 induces cyclin A- and E-associated kinase activities independently from cell cycle position. Oncogene 14: 2251 2257 